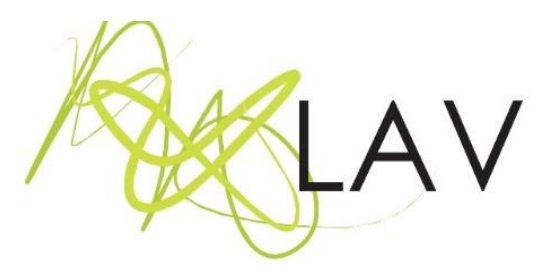

\title{
Ravena e o fim do Império Romano Ocidental: construção imagética do Christus Militans
}

Ravenna and the end of the Western Roman Empire: imagery construction of Christus Militans

Jack Brandãoi

Universidade de Santo Amaro

Christine Meierii

Universidade de Santo Amaro

Ricardo Alexandre Ramos ${ }^{\mathrm{iii}}$

Universidade de Santo Amaro

\section{Resumo}

Este artigo tem como objetivo apresentar o Christus Militans, mosaico da capela arcebispal de Ravena, uma obra que chama a atenção não só por sua beleza, mas, sobretudo, por sua temática. Isso porque, acostumados com a mensagem pacífica e salvadora de Cristo, o leitor pode ser levado ao estranhamento ao ver representado um Cristo cuja imagem se aproxima à de um soldado. Além disso, pretendemos discorrer sobre a questão iconológica e sua tradição presentes nessa representação.

Palavras-Chave Ravena, Christus Militans, mosaico, iconologia.

\section{Abstract}

This article aims to present the Christus Militans, mosaic of the archbishop's chapel of Ravenna, a work that attracts attention not only for its beauty, but above all for its theme. This is because, accustomed to the peaceful and saving message of Christ, the reader can be led into estrangement by seeing represented a Christ whose image resemble a soldier. In addition, we intend to discuss the iconological issue and its tradition present in this representation.

Keywords Ravenna, Christus Militans, mosaic, iconology.

\section{Introdução}

Com a vitória de Constantino sob Maxêncio (312 d.C.), sua ascensão ao trono imperial e o estabelecimento do Édito de Milão (313 d.C.), concedendo a liberdade religiosa no Império, abriu-se o caminho para que o cristianismo não só triunfasse sobre as antigas religiões pagãs, como também se tornasse, em seguida, a nova religião de Estado.

Revista Digital do LAV - Santa Maria - vol. 11, n. 1, p. 140-160 - jan./abr. 2018 ISSN 1983 - 7348 http://dx.doi.org/10.5902/1983734828890 
Assim, mais que uma mera autorização para construir templos para abrigar a comunidade cristã, o próprio imperador ordena a construção de grandes basílicas, como a da Natividade (326 d.C.), a do Santo Sepulcro (335 d.C.) e a de São Pedro (360 d.C.): os cristãos não precisariam mais se reunir em casas particulares (domus eclesiae), nas catacumbas ou em templos rudimentares, a fim de realizar seu culto, agora poderiam fazê-lo em locais públicos.

Em finais do século $V$ e início do VI, o cristianismo já estava, de certa maneira, estabelecido, tendo suas raízes em duas grandes culturas mediterrânicas: a judaica e a grega. No entanto, ambas possuíam formas, diametralmente, diversas de representar o divino. Se, por um lado, esta é mimética e antropomórfica, aquela não aceita e até condena a representação figurativa de Deus. O cristianismo, porém, supera tais preceitos e sintetiza a representação naturalista e icônica de uma, com a não iconicidade de outra; estabelecendo, assim, uma solução simbólica, significa algo além de si mesma.

O Christus Militans - objeto de estudo deste artigo - foi, claramente, concebido dessa maneira (figura 01): é figuração, mas aponta para outro significado; além disso, não é mimético, tampouco icônico - é um símbolo de Cristo. Tal representação, por sua vez, tem suas raízes em outras, largamente conhecidas no império: nas moedas - como a representação de Marte (figura 06) -, nas estátuas (figura 02), bem como na arte monumental (figura 03).

No final do séc. V, a capital do Império Ocidental, que era Milão, é transferida para Ravena, alterando a então cidade provinciana por meio de edifícios importantes e dignos do seu novo status. Localizada no nordeste da Península Itálica, tornou-se a última capital do Império Romano do Ocidente.

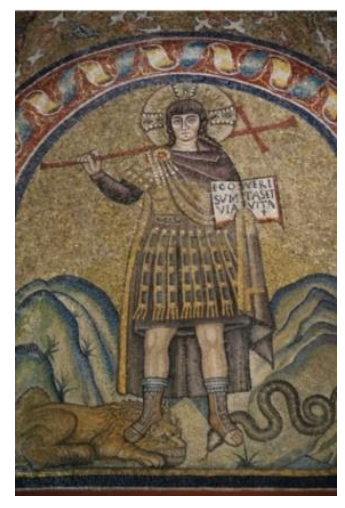

Figura. 01 - O Cristo Guerreiro, Ravena, séc. V. 
Cercada por pântanos, possuía um bom acesso por mar, tornando-se um importante porto naval imperial e, apesar de localizada próxima às rotas utilizadas pelos bárbaros, era bem protegida. Isso, contudo, não foi suficiente para mantê-la diante do colapso do Império. Odoacro, antigo soldado mercenário a serviço do cambaleante Império Romano Ocidental, é aclamado rex gentium por suas tropas, tornando-se rei da Itália. No entanto, por meio de intrigas do imperador Zenão, do Oriente, é sucedido pelo ostrogodo Teodorico, em cujo reinado a obra, objeto de estudo deste artigo, foi, provavelmente, encomendada e executada.

\section{As artes monumental e sagrada}

Com construções de grandes proporções, não só a concepção de espacialidade é importante, como também a de luminosidade e a de ornamentação, levando as pessoas que transitam por esses lugares a certo arrebatamento. Basta pensarmos, por exemplo, na grandiosidade do Fórum de Trajano, inaugurado em 112 d.C., com sua monumental basílica; a Úlpia, suas bibliotecas, sua coluna comemorativa repleta de imagens em baixo relevo, narrando a vitória do imperador sobre os dácios; ou a basílica de Constantino (figura 03), erigida no Fórum romano, com sua imensa altura, suas abóbadas de caixote e suas grandes estátuas, cujos resquícios ainda podem ser vistos hoje.

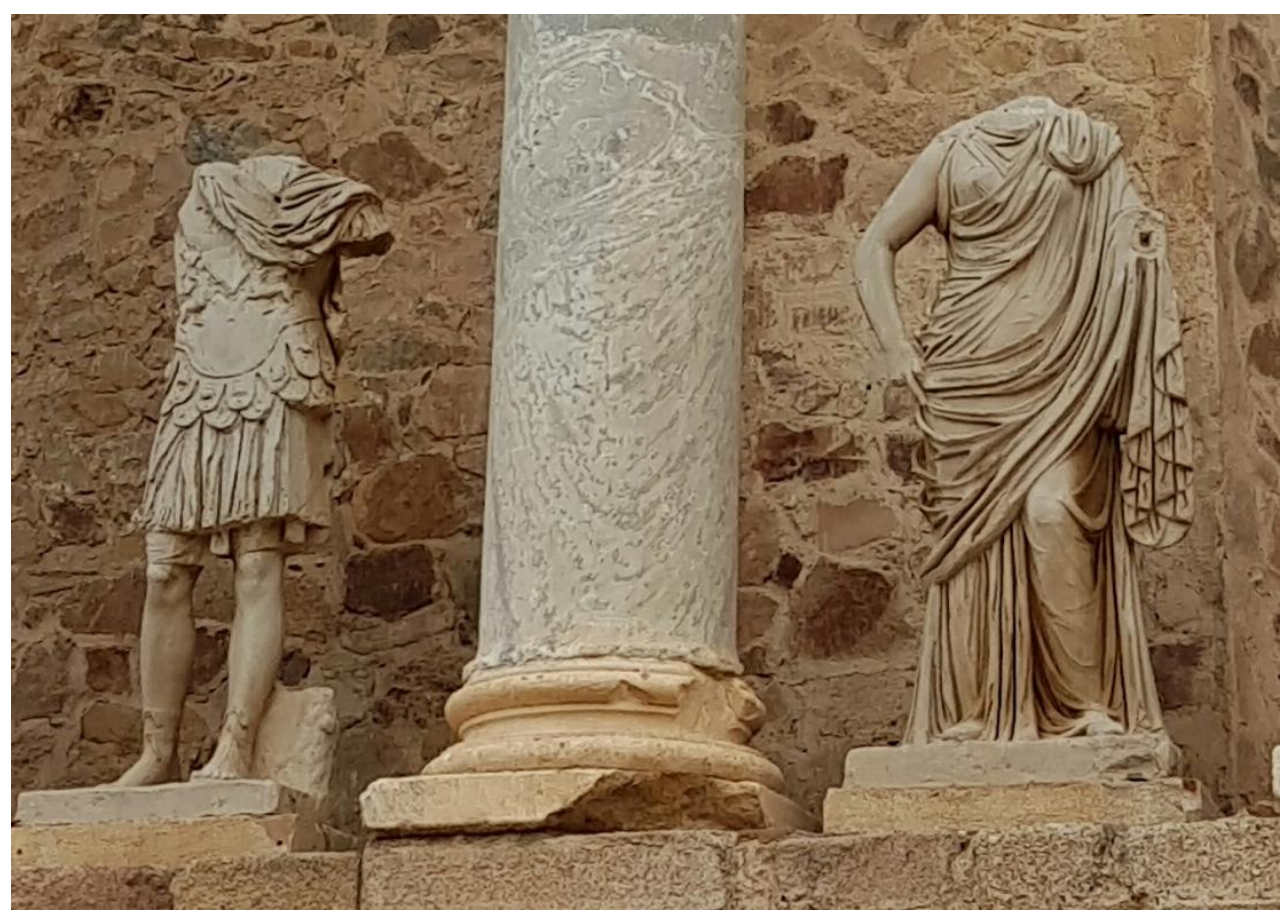

Figura. 02

Estátuas de teatro romano, Mérida, Espanha séc. I d.C.

(foto de Christiane Meier). 
Quando o imperador se converte ao cristianismo e passa a comissionar igrejas, os artistas, na falta de cânones cristãos, utilizam-se da linguagem conhecida na época, ressignificando-a. Nesse período, ainda não há nem a escolha voluntária de quem encomendou, tampouco da Igreja: era uma opção pessoal dos artistas que empregavam a linguagem e a técnica conhecidas.

Não poderia ser diferente na Ravena almejada por Teodorico o qual cultuava a grandiosidade de Roma, por isso não poupava esforços em suas construções, erigidas pelos melhores arquitetos, e em suas ornamentações executadas pelos mais talentosos artistas do decadente Império.

Muitos dos monumentos da cidade que existem até hoje - Mausoléu de Galla Placídia, o Batistério Neoniano (figura 03), o Batistério Ariano, a Basílica de Santo Apolinário Nuovo, a Capela Arcebispal, o Mausoléu de Teodorico, a Igreja de San Vitale e a Basílica de Santo Apolinário in Classe -, são ímpares e, como uma cápsula do tempo, mostramnos não apenas um fazer artístico, mas também o pensamento dos primeiros séculos do cristianismo. Não à toa estão inseridos na lista do Patrimônio da Humanidade:

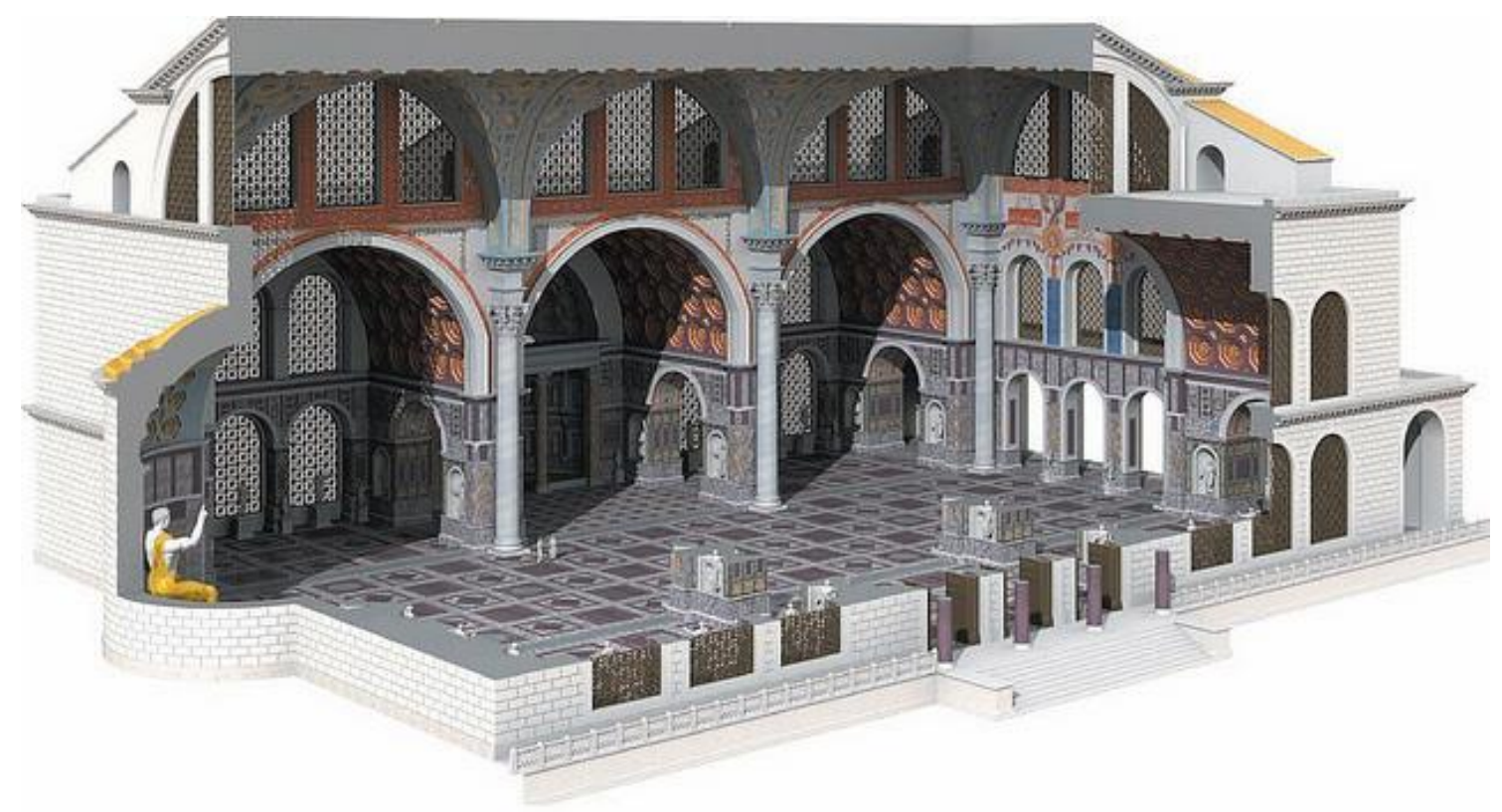

Figura. 03

Basílica de Constantino, 306-312, Roma, Itália

(Modelo computadorizado por John Burge). 
These religious monuments, decorated with precious marble, stuccos and mosaics, reflect the major historical, political and religious events that took place in Ravenna, which became the capital of the Western Roman Empire in $402 \mathrm{AD}$, and remained prominent first Ostrogothic and then Byzantine capital in Italy through the fifth and sixth centuries. [...] The Early Christian buildings of Ravenna are unique testimonies of the artistic contacts and developments in a highly significant period of the cultural development in Europe. They constitute an epitome of religious and funerary art and architecture during the 5th and 6th centuries AD. The mosaics are among the best surviving examples of this form of art in Europe and have added significance due to the blending of western and eastern motifs and techniques ${ }^{1}$ (UNESCO, 1996, s/p).

Muitos desses prédios derivam-se do final do Império, cuja linguagem artística foi, de certa maneira, assimilada pela nova doutrina e por ela empregada. Isso fica claro quando do uso das tradições romanas e de sua matriz estética, adotada sem reservas, como sua forma, sua estrutura e, inclusive, partes de seu cerimonial.

Dessa maneira, não seria difícil fazer a transposição da estética que refletia a riqueza e a grandeza do monarca, na imagem do imperador, ou a de um deus poderoso como Apolo, ressignificando-a com a força espiritual do novo Deus, o Cristo Pantocrator $^{2}$, por exemplo, dando início a uma nova arte sagrada.

Assim, a capela arcebispal de Ravena é um edifício sacro, onde tanto a arquitetura quanto a ornamentação têm uma finalidade: dar suporte ao culto e à liturgia ali realizada. Interessante perceber que, segundo Burckhardt (2004), o emprego de tal termo, gera, inclusive, problemas conceituais entre os historiadores de arte que 0 aplicam

[...] para designar toda e qualquer obra de tema religioso, [mas] esquecem-se de que a arte é essencialmente forma. Para que uma obra de arte possa ser propriamente qualificada de 'sagrada', não basta que seus temas derivem de uma verdade espiritual. É necessário, também, que sua linguagem formal testemunhe e manifeste essa origem [...]. Nenhuma categoria de arte pode ser definida como sagrada a menos que também sua forma reflita a visão espiritual característica da religião

\footnotetext{
1 [Estes monumentos religiosos, decorados com mármores preciosos, estuques e mosaicos, refletem os principais eventos históricos, políticos e religiosos que ocorreram em Ravenna, que se tornou a capital do Império Romano do Ocidente em 402 d.C. e manteve-se proeminente como primeira capital ostrogoda e depois capital bizantina na Itália até o quinto e sexto séculos. [...]

Os primeiros edifícios cristãos de Ravenna são testemunhos únicos dos contatos artísticos e desenvolvimentos em um período altamente significativo do desenvolvimento cultural na Europa. Constituem um epítome de arte e arquitetura religiosa e funerária nos séculos V e VI d. C. Os mosaicos estão entre os melhores exemplos sobreviventes desta forma de arte na Europa e têm significado adicional devido à mistura de motivos e técnicas ocidentais e orientais. (tradução nossa)

${ }^{2} \mathrm{Na}$ iconografia cristã, é a representação majestática de Jesus como Senhor Todo Poderoso, tendo a mão direita levantada em sinal de bênção e a esquerda segurando os Evangelhos ou as Escrituras.
} 
da qual provém (BURCKHARDT, 2004, p. 17-18).

Se olharmos em torno da capela, perceberemos que ela segue um cânone simbólico que se baseia

[...] em uma ciência das formas, ou, em outras palavras, no simbolismo inerente às formas [...]. É preciso que se tenha em mente que um símbolo não é apenas um sinal estabelecido convencionalmente, mas manifesta seu arquétipo em virtude de uma lei ontológica definida; [...] um símbolo é, de certo modo, aquilo que exprime (BURCKHARDT, 2004, p. 18).

Salta-nos aos olhos, antes de adentrarmos no recinto sagrado, sua antessala e seu belo Cristo, sobre a porta de entrada. Tal imagem pretende não apenas evocar sentimentos, nem transmitir meras impressões (ibidem) por meio de opções complexas, pois "bastam-Ihe meios simples e primordiais" (BURCKHARDT, 2004, p. 20).

Nem poderia ser diferente, visto que "seu objeto real é o inefável" (BURCKHARDT, 2004, p. 20), contudo "é preciso ficar bem claro que isso não significa, de modo algum, copiar a criação divina acabada, isto é, o mundo como o vemos [...]. Um 'naturalismo' literal está, portanto, excluído da arte sagrada" (BURCKHARDT, 2004, p. 21), logo a mimese não é seu fim. $O$ arquiteto, os construtores e os artistas que ali trabalharam não a buscavam, nem possuíam a intenção de dar vazão a seus sentimentos e convicções, isso porque estavam a serviço da Igreja e da construção - sem o saber ao certo - de um novo cânone.

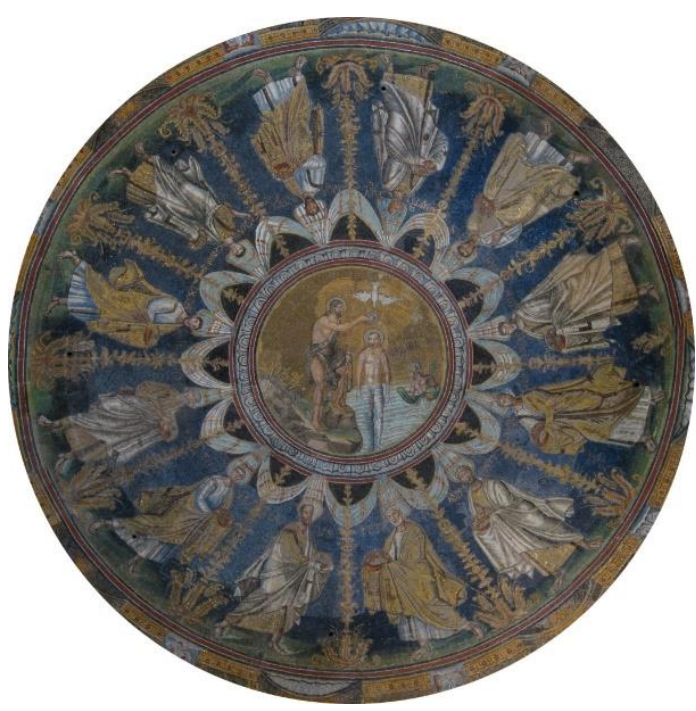

Figura. 04 - A capela arcebispal - Batistério neoniano, séc. IV, Ravena, Itália (Foto de Hay Kranen). 
Nesta época, também se professava, em Ravena, o arianismo, corrente que não aceitava a consubstanciação entre o Pai e o Filho, logo negavam a Trindade. Teodorico era um de seus adeptos e, apesar de ter mandado construir alguns monumentos arianos, não interferia na corrente trinitária; havia, inclusive, a duplicação e a convivência de muitos edifícios religiosos, cuja matriz imperial era romana e trinitária, ao lado de outros arianos, como um batistério para cada uma das correntes.

A capela, encomendada provavelmente pelo arcebispo Pedro II (494-519), foi consagrada a Cristo, sendo, posteriormente, dedicada a Santo André, cujas relíquias foram trazidas, no séc. VI, de Constantinopla para Ravena. O vestíbulo é retangular e o oratório em forma de cruz grega. As paredes de ambos são revestidas, na parte inferior, por grandes placas de mármore e, na superior, por mosaicos de tessela, compostos

[...] de pequenos pedaços de massa vítrea; essas pastilhas, porém, não têm todas o mesmo tamanho, a mesma forma, a mesma transparência, a mesma qualidade reflexiva e, além disso, são fixadas na argamassa do reboco em diversos níveis e com diversas inclinações [...]. A superfície desigual que assim se obtém reflete a luz, refratando-a em infinitos raios [...] (ARGAN, 2003, p. 254).

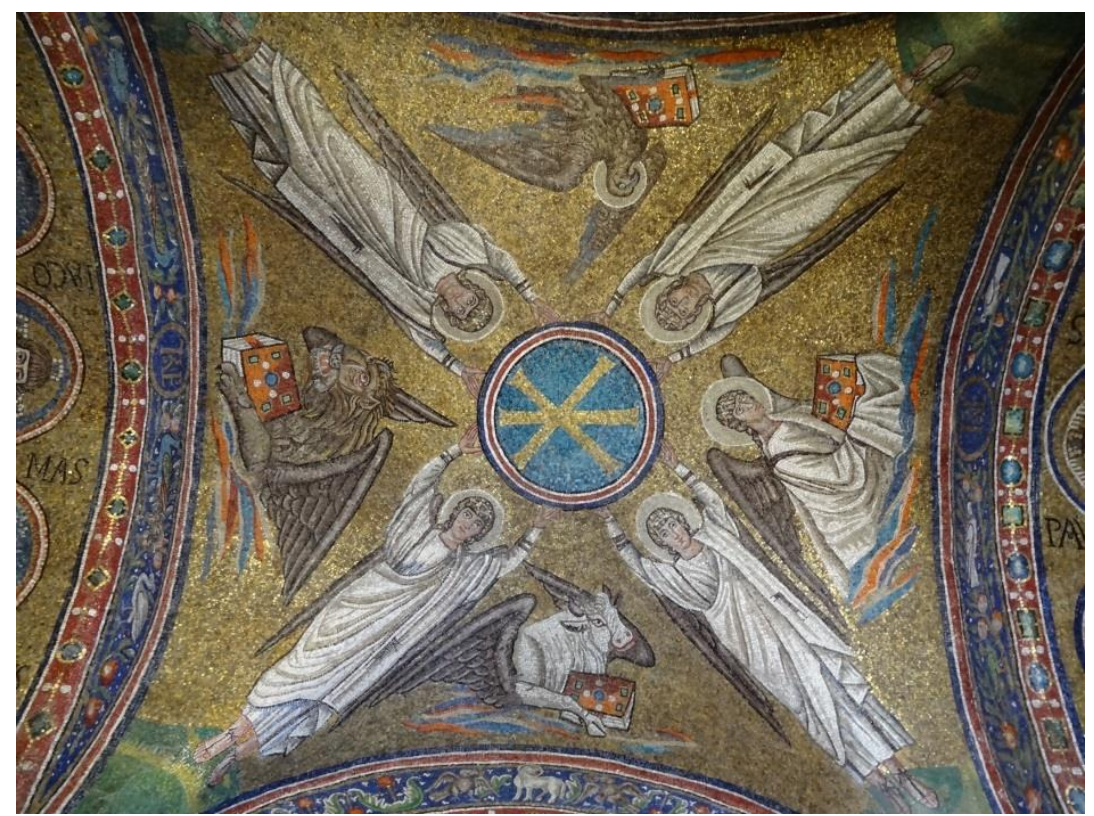

Figura. 05

Capela arcebispal de Ravena, teto, séc. V.

O teto (figura 05) de ambos também tem, igualmente, esse revestimento, confeccionado na época da construção da capela. Sobre a porta de acesso ao oratório vemos o Christus Militans. Além disso, podemos observar, nas paredes laterais, entre o 
revestimento de mármore e o teto, quatro grandes mosaicos dentro de painéis quadrados, contendo vinte hexâmetros em latim. A primeira inscrição resume o que encontraremos no interior da capela: Aut lux hic nata est, aut capta hic libera regnat ${ }^{3}$.

A arte mural romana, com suas variadas soluções de revestimento (mármore, estuque, pintura e mosaicos), sempre buscou a luminosidade. Os artistas estudavam, incessantemente, os efeitos de transparência, luz e sombra, não só nas superfícies de paredes, mas também em esculturas e em baixos-relevos; e o emprego do mosaico se presta especialmente para isso; já que, como vimos acima, a refração da luz das tesselas proporciona esta luminosidade tão desejada.

É preciso mencionar ainda que, na era paleocristã, quando o mosaico deixa de ser utilizado no pavimento e passa para as paredes, não só deixa de ser submetido ao desgaste, como também se abrem várias opções de emprego, já que ao ser confeccionado com um material menos resistente, como as pastilhas de vidro, obtémse o efeito da luminosidade tão desejado por arquitetos e artistas da época. Além desse resultado, há uma perfeita adequação da matéria à ideologia do momento, ao pensamento neoplatônico plotiniano como Argan (2003) tão bem pontua:

No plano ideológico, a técnica do mosaico aparece perfeitamente coerente com o pensamento da época [...] a técnica mosaica é propriamente o processo de restituição da matéria, de sua condição de opacidade à condição espiritual, da transparência, da luz, do espaço (ARGAN, 2003, p. 254).

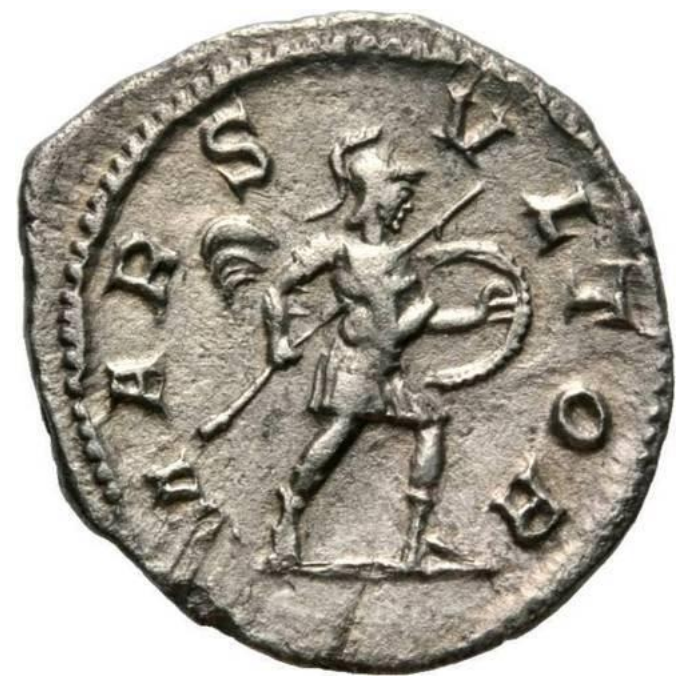

Figura. 06

Denário do período imperial com deus Marte, séc. III d.C.

${ }^{3}$ [Ou a luz aqui nasceu, ou então foi aqui capturada e reina livremente]. 
O mosaico, porém, tem suas desvantagens, que cabe ao mosaicista resolver:

[...] a matéria não the permite misturar as cores, usa o recurso de iluminar áreas mais frias (por exemplo, de azuis e verdes), inserindo no conjunto algumas notas quentes (amarelos, vermelhos) ou mesmo, inversamente, rebaixando um matiz muito forte com outro mais brando (ARGAN, 2003, p. 255).

Portanto, conforme nos diz o hexâmetro em sua parede, parece que a questão da luminosidade foi bem resolvida nesse espaço, encantando aqueles que por lá passaram.

\section{O Cristo Guerreiro}

Ao observarmos o Cristo Guerreiro (figura. 01), veremos que mesmo não sendo uma imagem naturalista, tampouco é apenas esquematizada ou mesmo com formas chapadas, possui certo volume, mas é isento de movimento; além disso, é monumental e apolíneo. Apesar disso e do emprego esquemático presente no Império, temos uma imagem ressignificada, ou seja, mesma forma, mas conteúdo novo: arte monumental, porém cristã.
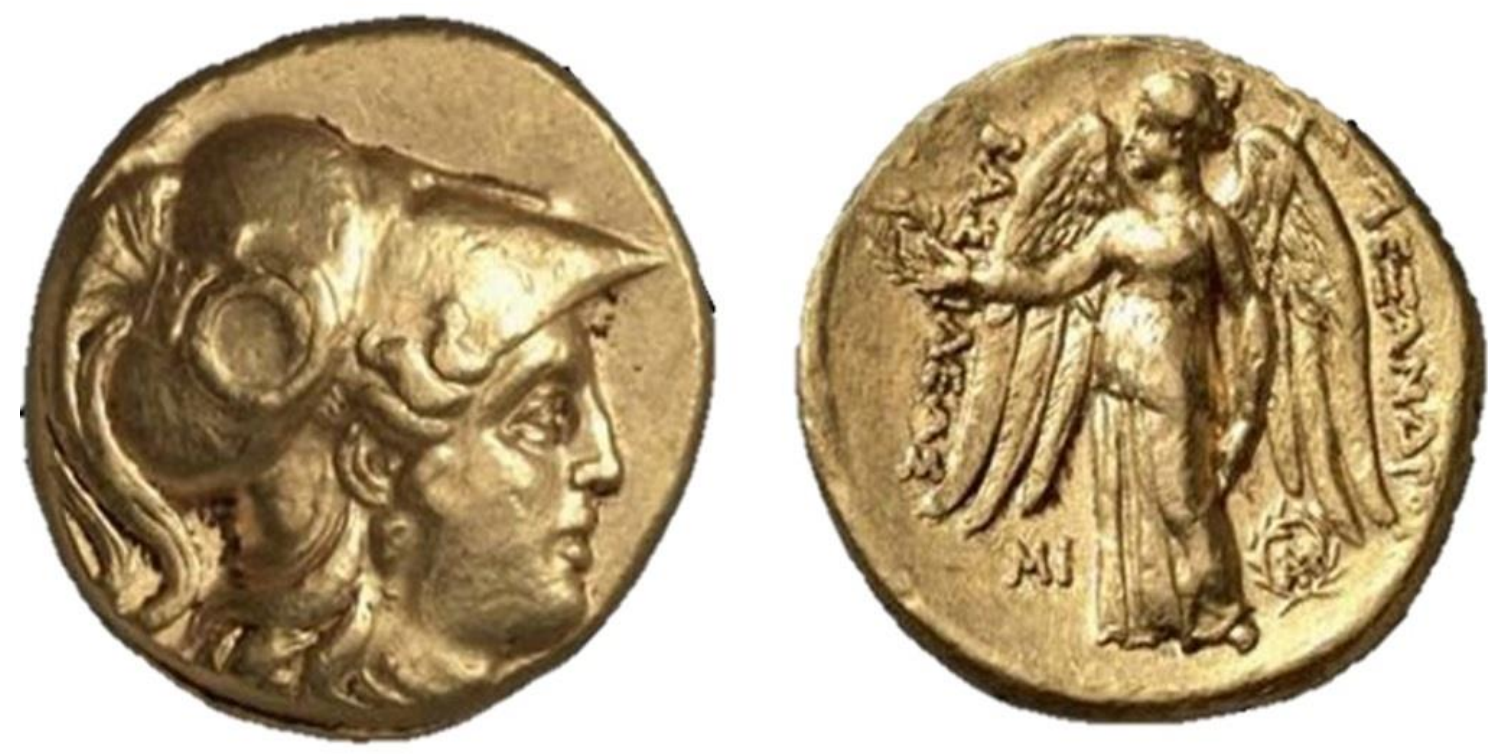

Figura. 07

Moeda cunhada na Babilônia; no anverso, busto de Alexandre Magno, no reverso, Nike/Nitória, 323-317 a.C. 
Vemos um Cristo que lembra, inclusive, o deus Marte (figura 05), só que no lugar da lança, vemos a cruz; e no lugar do escudo, vemos as Escrituras. Tal representação também pode remeter-nos tanto a Alexandre Magno, rei da Macedônia e conquistador da Pérsia: rosto imberbe e jovem, corpo inteiro, frontal, de pé, aspecto saudável, ar vencedor, refletindo sua grandeza terrestre, conforme é possível ver na moeda da figura 07, cujo reverso mostra Nike, a deusa da Vitória com seu cetro; quanto a Otávio Augusto, primeiro imperador de Roma.

Há, no rosto do Cristo de Ravena, grandes olhos escuros, nariz e sobrancelhas desenhados em linha contínua, boca pequena, queixo marcado, bochechas rosadas. Não é um rosto com cicatrizes de batalhas, endurecido pela guerra; pelo contrário, mostrase isento de marcas bélicas, é jovem e tem uma pele lisa. Um rosto sereno e contido. Apesar dessas características, não se percebe qualquer interferência dos sentimentos do artista, ao destacar esta ou aquela parte do retratado, afinal se busca criar uma obra puramente simbólica.

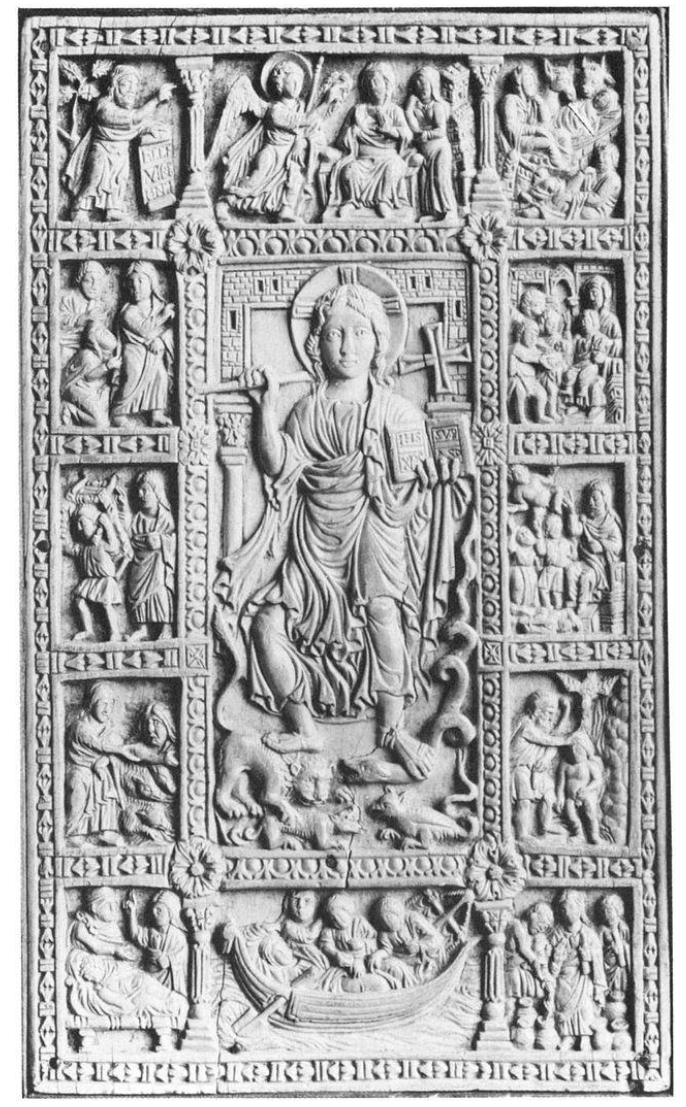

Figura. 08

Cristo vitorioso, capa do Evangeliário de Chelles, marfim, 800 d.C., Biblioteca Bodleian, Oxford, Inglaterra. 
Ao determos nosso olhar acima da cabeça, em seu nimbo, veremos um círculo com intensa luminosidade dourada, cruz ricamente trabalhada, como uma coroa. Não estamos diante de um imperador romano, como Augusto (figura 10), mas do Cristo, rei dos reis, do Christus Victor, como no denário retratando Marte (Mars Victor).

O Cristo que o artista nos apresenta é majestático, um novo imperador que venceu o mal, o pecado e a morte; mas, à diferença dos outros, não por meio da opressão, mas da salvação de seus súditos: "Meu reino não é deste mundo. Se meu reino fosse deste mundo, meus súditos teriam combatido para que eu não fosse entregue aos judeus. Mas meu reino não é daqui" (Jo 18,36).

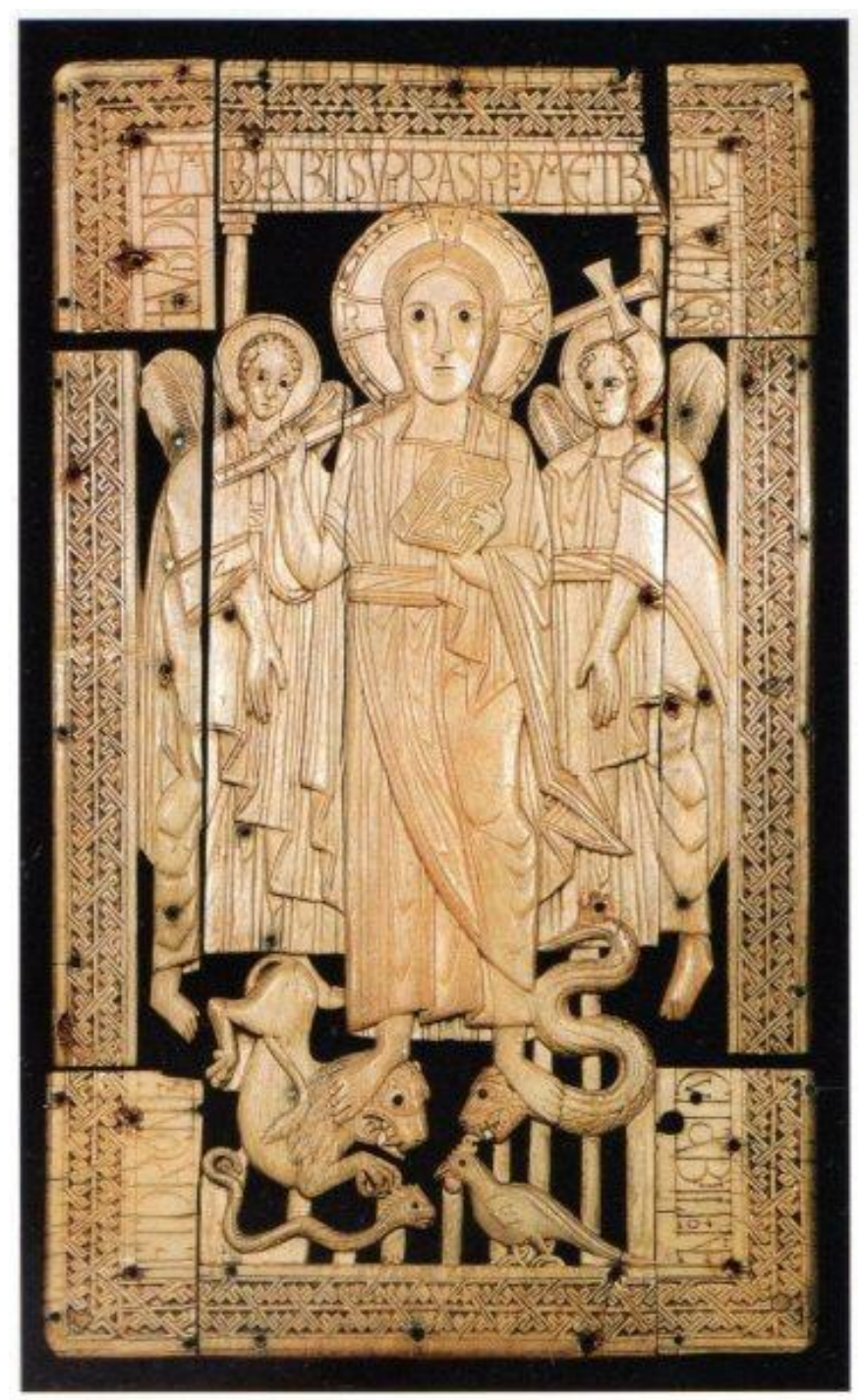

Figura. 09

Cristo Vitorioso, capa do Evangélio de Genoels-Elderen, marfim, 800 d.C. Museu Real de Arte e História, Bruxelas, Bélgica.

Podemos ponderar se se trata realmente de um Cristo Guerreiro, como a obra é 
conhecida, de um Cristo Vitorioso, como alguns a chamam, ou mesmo um Príncipe da Paz. Observemos a vestimenta imperial, longo manto preso ao ombro por fíbula ornamentada, formando belo drapeado. Nos pés, sandálias ricamente decoradas. Com uma das mãos, carrega sobre os ombros uma cruz, fina e longa, quase uma espada.

Não a segura pelo cabo, isto é, não a empunha como um guerreiro o faria, mas o faz pela parte inferior, pela parte mais longa: a cruz é leve, não pesa em seus ombros, como uma arma letal.

Essa cruz, símbolo da ressurreição, representa o triunfo sobre a morte e sobre o mal, tanto em imagens do período (figuras 08 e 09), quanto em séculos ulteriores. Convém lembrar que, nos primeiros tempos do cristianismo, os artistas abstinham-se de empregar a cruz, preferindo estilizá-la, "por meio de outros símbolos como a âncora $[\ldots]$, já que ainda representava a ignomínia, afinal era um suplício aplicado aos párias da sociedade" (BRANDÃO, 2010, p. 15), a retratar o Cristo crucificado e sofredor: "a representação da crucificação e do sofrimento como motivo iconográfico aparecerá em um momento posterior, apenas no século V, e de forma comedida" (BRANDÃO, 2014, p. 132).

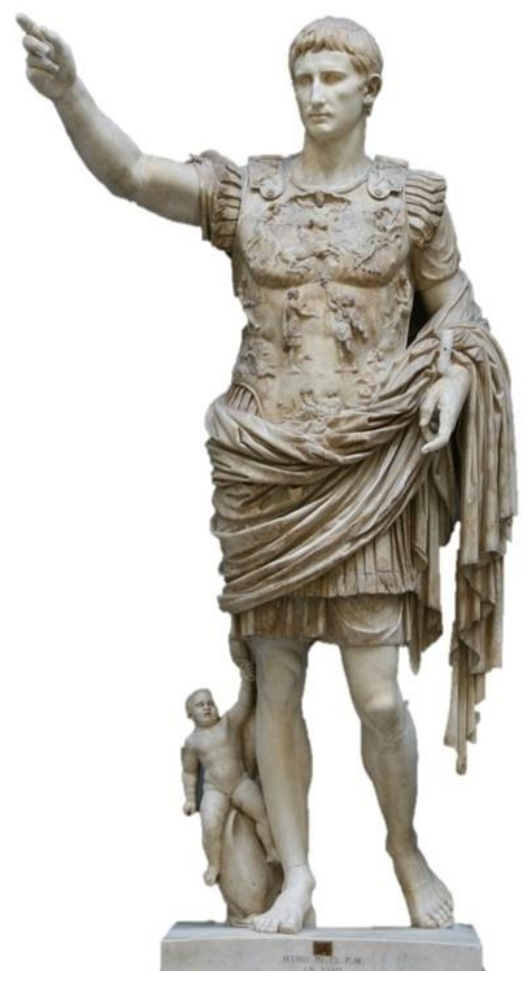

Figura. 10

Augusto prima porta, mármore, cerca do ano 14 d.C., Museu do Vaticano. 
Portanto, a ênfase iconográfica de Jesus era dada a glória de sua ressurreição, sequer o mostravam carregando a cruz: não sentiam a necessidade de exaltarem seu martírio. É possível perceber isso nas figuras 11 e 12, pois na representação de "Cristo carregando a cruz", o artista retrata Simão Cireneu executando a tarefa. Se, por acaso, representasse o próprio Cristo, Ele a levaria ao ombro, mas ela seria leve, a cruz da ressurreição, semelhante à do Christus Militans (figuras 08 e 09), não a da dor e do sofrimento. Convém ressaltar que o modelo empregado a Jesus era o imperial, majestático, triunfante, que vigorou durante séculos, nunca o do derrotado ou do sofredor.

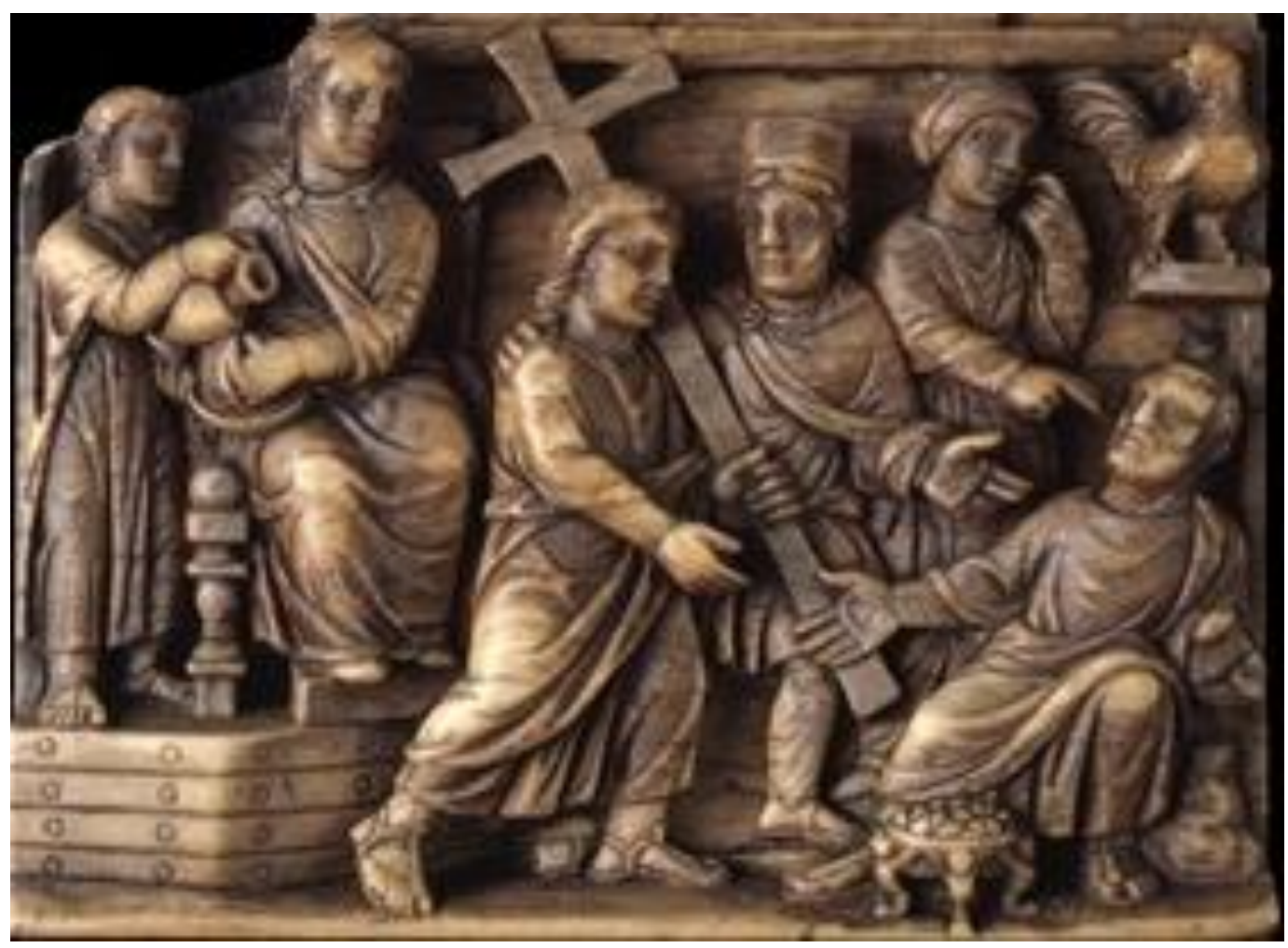

Figura. 11

Cristo carregando a cruz, marfim, início do século $\mathrm{V}$ British Museum, Londres.

Se o Cristo de Ravena empunha a cruz com a mão direita, com a esquerda segura um Livro aberto - onde se lê Ego sum via veritas et vita ${ }^{4}$ - sem tocá-lo diretamente, já que o segura com sua mão envolta no manto, demonstrando, com esse gesto, a sacralidade das palavras ali contidas.

\footnotetext{
4 "Eu sou o Caminho, a Verdade e a Vida". (Jo 14, 6)
} 
São estas, portanto, as armas do Cristo Guerreiro/Vitorioso: a cruz da ressurreição e o livro. Não lutou com a espada, mas pregando o Evangelho e aceitando seu sacrifício; ressuscitado, liberta a humanidade do mal e da morte. O exemplo do Príncipe da Paz, lutando com armas não convencionais, se multiplica rapidamente na Igreja. Ensina-nos Efrem da Síria, um dos doutores da Igreja, sobre o sinal da cruz: "Ao invés de se proteger com o escudo, proteja-se com o precioso sinal da cruz, selando teus membros e teu coração [...] sele primeiro com o sinal da cruz em nome do Pai e do Filho e do Espírito Santo"5 (DIE DEUTSCHEN BISCHÖFE, 2006, s/p, tradução nossa).

É possível perceber que Cristo calca com seus pés dois animais: o leão e a serpente. Esta, presente no imaginário judaico-cristão, é uma alusão à desobediência de Adão e Eva no Paraíso, pois ao persuadir e convencer a mulher para que comesse o fruto proibido, legou a morte à humanidade. Aquele se refere ao demônio; pois, conforme dizia São Pedro, "o diabo, que é o inimigo de vocês, vos rodeia como um leão que ruge, procurando a quem devorar" (1Pe 5,8$)$.

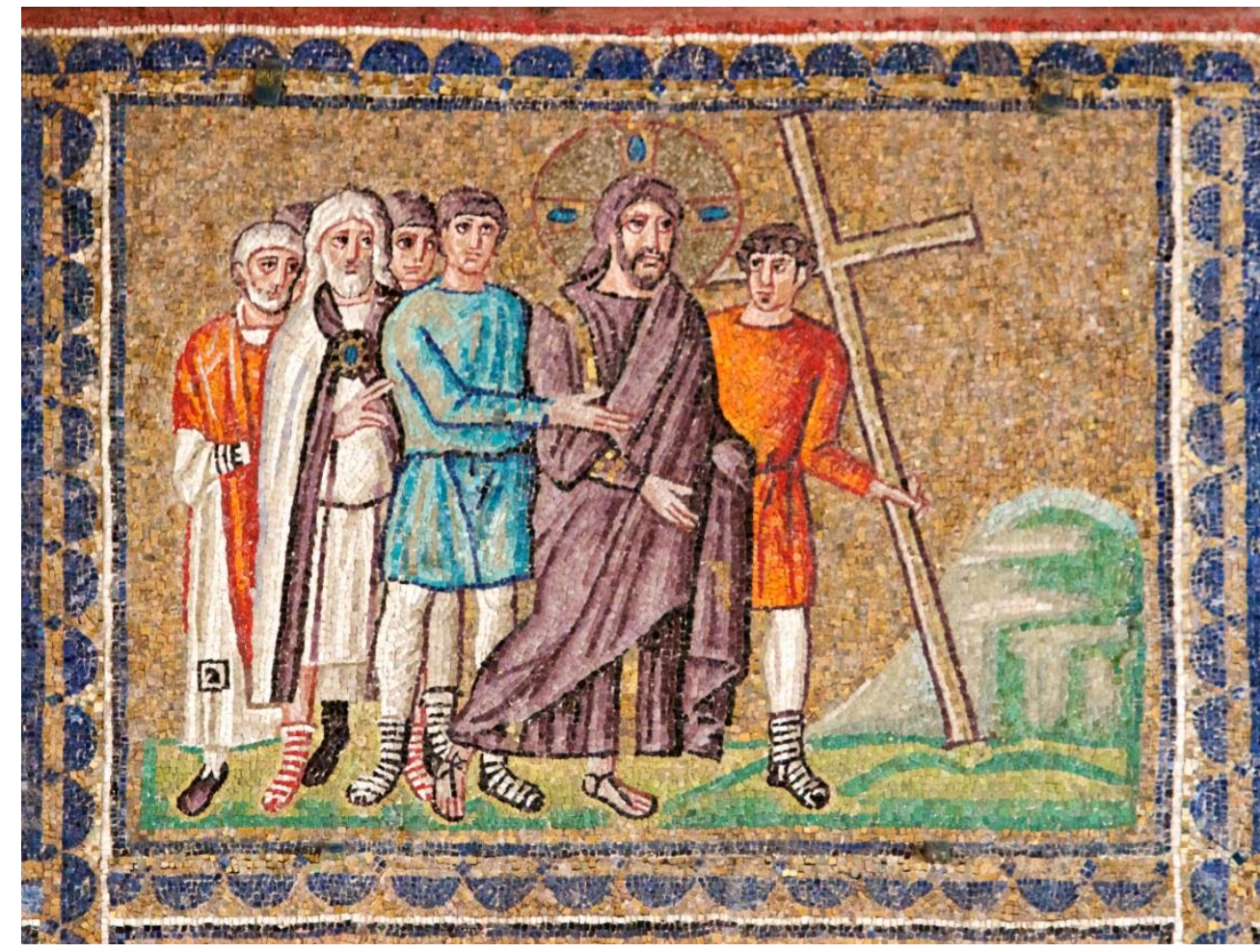

Figura. 12

Jesus é conduzido ao Gólgota (foto de Nick Thompson), Igreja de Sant'Apollinare Nuovo, Ravena, Italia, século V.

\footnotetext{
5 "Anstatt mit dem Schild bedecke dich mit dem kostbaren Kreuz, indem du alle deine Glieder und dein Herz besiegelst. [...] versiegle zuerst mit dem Kreuz im Namen des Vaters und des Sohnes und des Heiligen Geistes".
}

Revista Digital do LAV - Santa Maria - vol. 11, n. 1, p. 140-160 - jan./abr. 2018 ISSN 1983 - 7348 http://dx.doi.org/10.5902/1983734828890 
É importante ressaltar, porém, que a significação imagética de tais animais não se restringe apenas a tais conceitos, pelo contrário. Se sairmos da órbita da tradição judaico-cristã, com a qual estamos trabalhando, e ampliarmos o escopo para a Antiguidade, veremos que a serpente, por exemplo, tem uma conotação muito diferente da negativa que concebemos.

Se nos basearmos na obra Hieroglyphica de Horapolo (2011), que teve grande influência no pensamento europeu a partir do século XVI, estendendo-se até o XIX, e influenciou diversos artistas como Alberti, Bramante, Dürer, Leonardo da Vinci, Vasari, veremos que para os egípcios, pelo menos segundo o autor, a concepção é muito distinta, pois tal povo via nesse réptil um animal sagrado, de natureza divina.

Assim, a serpente, em diversos contextos, poderia tanto representar o universo ou a eternidade, quando é apresentada mordendo a própria cauda (HORAPOLO, 2011); quanto conceber um rei muito poderoso (HORAPOLO, 2011), como fez Rubens, ao retratar o nascimento de Luís XIII da França, mostrando o jovem que segura o futuro rei rodeado por uma serpente (figura 13). A serpente também poderia representar um "senhor do mundo" (HORAPOLO, 2011, p. 203) - como se intitulavam os reis helênicos ou romanos -, quando o animal encontra-se rodeando uma casa ou palácio (HORAPOLO, 2011, p. 203), um "senhor todo-poderoso" (HORAPOLO, 2011, p. 203), ou apenas um "rei que domina uma parte do mundo" (HORAPOLO, 2011, p. 203).

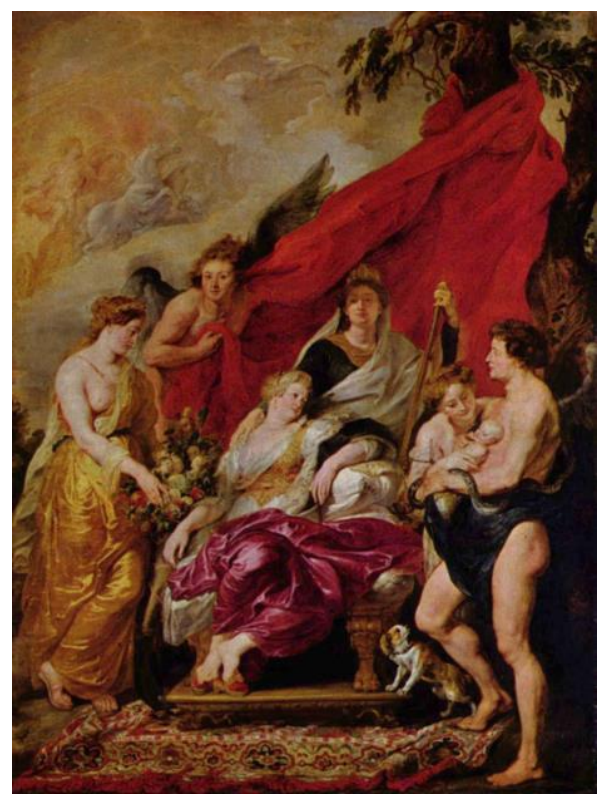

Figura. 13

Nascimento do Delfim Luís XIII, Rubens, 1622-1625 Musée du Louvre. 
De maneira semelhante à serpente, a imagem do leão também possui inúmeras significações, sejam positivas - coragem, grandeza, robustez de ânimo, força física, temperança, valor, virtude heroica, vigilância -, sejam negativas - temor, terror, cólera, ambição, ferocidade -, além de participar de diversas alegorias.

Para os antigos, a evidente ferocidade do rei dos animais, beirava a irascibilidade e a cólera, descritas por Horapolo (2011), como ígnea e sem medidas, a ponto de ser levado a matar e a desossar seus próprios filhotes. Caso isso ocorresse, bastaria o simples atrito dos ossos roídos, para que se desprendessem, segundo certa imagem enraizada na Antiguidade, faíscas deles. O próprio Aristóteles, ao referir-se ao leão, afirmava que "sus huesos son muy duros, los más robustos de todos los animales, y que frotando uno contra outro sale fuego, como si se tratara de dos piedras ${ }^{6 \prime}$ (ARISTÓTELES apud HORAPOLO, 2011, p. 453, grifo nosso).

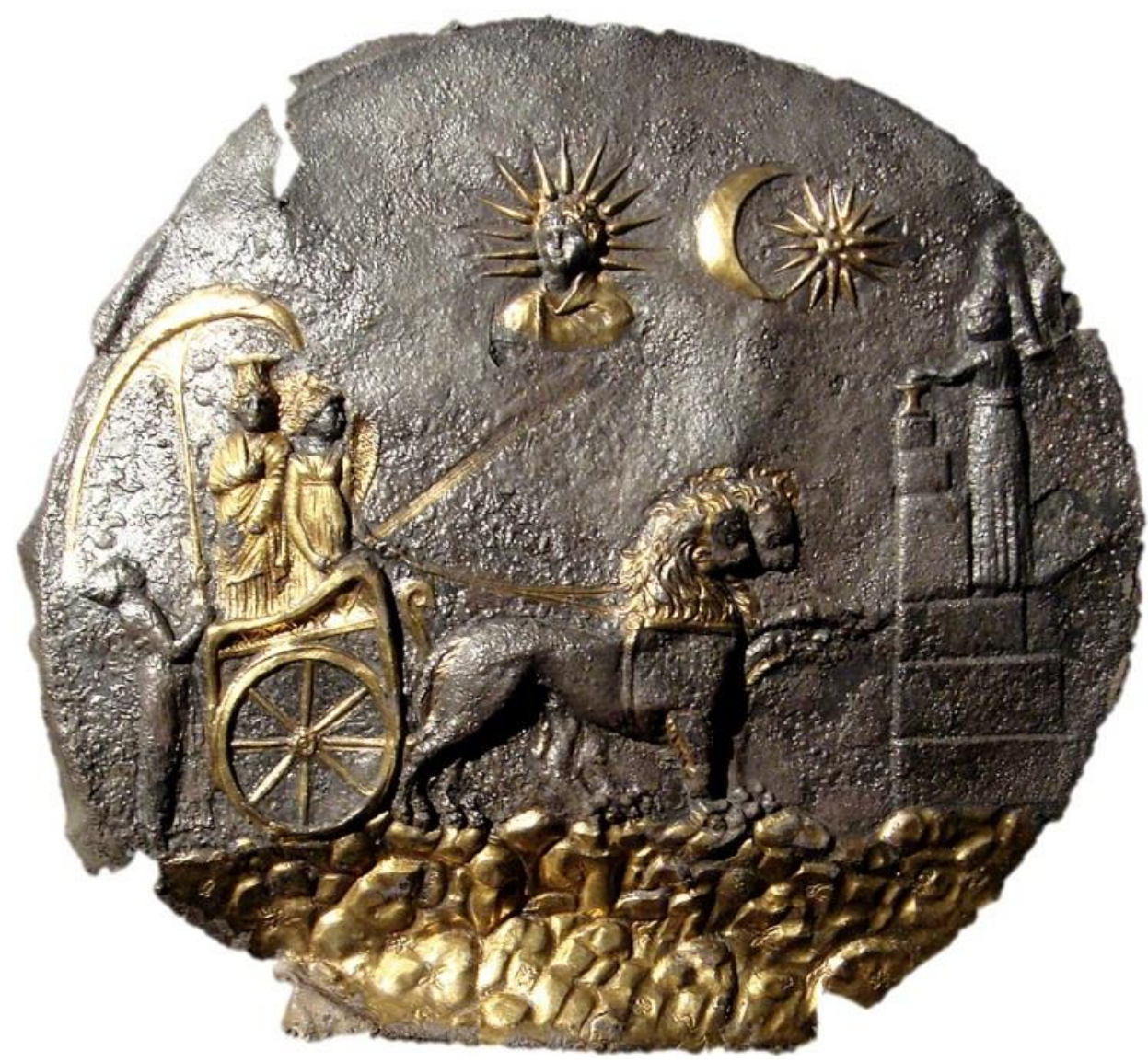

Figura. 14

Placa que retrata Cibele, um sacrifício votivo e o deus Sol, Ai Khanoum, século III a.C. Museu Nacional do Afeganistão.

\footnotetext{
${ }^{6}[(\ldots)$ seus ossos são muito duros, os mais resistentes de todos os animais, e que esfregando um contra o outro sai fogo, como se fossem duas pedras. (tradução nossa)]
} 
Havia, portanto, segundo tal pensamento, uma grande relação entre o "leão" e o "fogo"; afinal aquele era puro ardor e fogo que "le abrasa el interior" (ELIANO apud RIPA, 2007a, p. 399). Não à toa, Ripa emprega-o tanto em sua alegoria "Complexão colérica pelo fogo", quanto na referente a "Julho". O teórico procura explicar a relação entre o excessivo calor do verão - no hemisfério norte - e a posição que o sol toma junto à Constelação de Leão, mostrando que esse mês também reflete a natureza do animal, "ardiente y ferocísima" (RIPA, 2007a, p. 76), daí "simbolizándose por ello este tiempo con dicho signo, por cuanto el Sol, ascendiendo hasta él [constelação de Leão], produce um excessivo calor y sequedad7" (RIPA, 2007a, p. 76).

Assim, o Christus Militans, ao ser representado pisando o leão, subjuga todas as forças infernais representadas pelo fogo que abrasa, internamente a alma, conforme se pode ver na Parábola do rico e Lázaro:

Havia um homem rico que se vestia de púrpura e linho fino, e dava banquetes todos os dias. E um pobre chamado Lázaro, cheio de feridas, que estava caído à porta do rico. [...] aconteceu que o pobre morreu, e os anjos o levaram para junto de Abraão. Morreu também o rico, e foi enterrado. No inferno, em meio aos tormentos, o rico levantou os olhos, e viu de longe Abraão, com Lázaro a seu lado, então o rico gritou: "Pai Abraão, tem piedade de mim! Manda Lázaro molhar a ponta do dedo para me refrescar a língua, porque este fogo me atormenta." (LC 16, 19, 22-24, grifo nossos)

Ou ainda a imagem construída pelo Apocalipse que expõe a reconstrução de Céus e Terra após o Julgamento Final, quando tanto a "morte", quanto "a morada dos mortos" serão lançadas "no lago de fogo. O lago de fogo é a segunda morte" (Apo 20, 14), juntamente com aqueles que perecerão a Eternidade.

Há, ainda, outro elemento que deve ser lembrado em relação ao leão: sua relação com a terra, isso porque em diversas imagens que retratam a questão da agricultura e do manejo da terra, o leão está presente. É possível verificar isso nas representações da deusa Cibele - deusa da fertilidade, Magna Mater -, cujo carro era puxado por dois leões (figura 14).

O leão, portanto, pode tanto simbolizar as forças infernais, devido a seu fogo interior,

7 [É um animal de natureza ardente e ferocíssima, simbolizando por esse motivo este tempo com esse signo,
porque o Sol ascendendo até ela [constelação de Leão], produz calor e secura excessivos. (tradução nossa)].

Revista Digital do LAV - Santa Maria - vol. 11, n. 1, p. 140-160 - jan./abr. 2018 ISSN 1983 - 7348 http://dx.doi.org/10.5902/1983734828890 
quanto aos poderes terrestres que subjugam e levam à morte. Por fim, não se deve esquecer de que o próprio Cristo também possui essa representação, afinal Ele é o "Leão da tribo de Judá" (Ap 5, 5).

Além da subjugação desses animais pelo Christus Militans, pode-se observar, no mosaico, uma grande superfície dourada na parte superior da obra, um quase vazio, que contrasta com uma linha de montanhas na região inferior, presente nos dois lados do Cristo, sendo que seu lado direito está sarapintado com a representação de árvores semelhantes a palmeiras, enquanto a outra é nua, com a exceção de uma sob a serpente. Tais superfícies vazias dão, por seu lado, uma ênfase à imagem central.

Interessante perceber o emprego da palmeira, já que, na tradição que remonta ao judaísmo (SI 92, 13), ela simboliza o justo, aquele que não se dobra diante das injustiças e perseguições. Ripa (2007b), por sua vez, nos diz que ela é "símbolo del premio que en el Cielo reciben los que dominan sus pasiones, y a sí mismos se rigen y someten. En efecto la palma no se dobla por más que se someta a fuertes pesos, levantándose siempre, como dicen numerosos escritores"8 (RIPA, 2007b, p. 353).

Além disso, o próprio Jesus também pode estar associado a sua figura, devido à cena de sua entrada em Jerusalém, uma semana antes de sua Paixão e Morte, quando uma grande multidão, que viera para a festa da Páscoa, "apanhou ramos de palmeira e saiu ao seu encontro, gritando: 'Hosana! Bendito o que vem em nome do Senhor, o Rei de Israel!'" (Jo 12,13)

A multidão o aclamava, como se fazia a um rei que retornava em triunfo após uma expedição, no entanto esta ainda estava por vir: dar-se-ia no interior dos muros da cidade, levando-o a seu martírio. Não à toa, os mártires também seriam reconhecidos por trazer a palma da vitória em suas mãos. Símbolo também empregado pelo paganismo: Nike, por exemplo, também era representada com ramos de palma.

Interessante perceber que não somos nós que contemplamos o Cristo do mosaico, mas é Ele quem nos contempla. Há, dessa maneira, uma quase inversão da perspectiva, mesmo que esta inexista na obra, é evidente. Burckhardt (2004) nos diz que "Para o cristianismo, a imagem por excelência é a forma humana do Cristo. Disto decorre que a arte cristã tenha apenas um propósito: a transfiguração do homem" (BURCKHARDT,

\footnotetext{
${ }^{8}$ [(...) símbolo da recompensa que, no Céu, recebem aqueles que dominam suas paixões, e a si mesmos governam e se submetem. Na verdade, a palma não se dobra, por mais que esteja sujeita a pesos fortes, levantando-se sempre, como muitos escritores dizem. (tradução nossa)]
} 
2004, p. 23). E mais adiante ainda afirma que "a imagem de Cristo nada mais é que a projeção da descida do Verbo Divino à Terra" (BURCKHARDT, 2004, p. 113).

Por fim, vale comentar, brevemente, a rica moldura colorida que enquadra a obra. Podemos observar que a metade superior é formada por uma fita volumosa, central, espiralada que, por sua vez, está emoldurada por duas faixas acima e abaixo: uma cinza, mais grossa, e outra branca, fina. A metade inferior da moldura tem uma composição mais simples. As duas faixas cinza e vermelha descem, fechando-a abaixo. Assim, a moldura mais que enquadrar e delimitar nosso olhar, ajuda-nos a concentrarnos e contemplar a imagem do Cristo.

Quanto à paleta de cores do mosaico, o marrom, o roxo imperial e o dourado predominam com toques bege, vermelho queimado, azul e verde. Apesar de não haver muitas cores, vemos uma figura majestática: eis o Cristo que o artista deseja apresentar aos fiéis, um guerreiro que venceu, um mensageiro da paz e da fé de que nos livra da tentação, do mal e da morte.

\section{A porta}

Como afirmamos anteriormente, toda construção sacra segue cânones estritos e carrega em si muita simbologia. Nesta capela arcebispal não poderia ser diferente. Assim, precisamos perceber que o Cristo Guerreiro está colocado sobre a porta que dá acesso ao oratório. Seguramente, tal local não é fruto de uma mera ornamentação do espaço, pois simboliza a passagem de um mundo para outro. Toda a ornamentação escultural ou pictórica do portal relaciona-se ao significado espiritual da porta que, por sua vez, se identifica com a natureza do Homem-Deus (BURCKHARDT, 2004), que disse de si mesmo: "eu sou a porta. Quem entra por mim, será salvo" (Jo 10, 9).

Desta forma, o Cristo Guerreiro não poderia estar em outro local do vestíbulo se não sobre a porta. Ele convida o observador a passar por ela, a entrar na Casa de Deus (Domus Dei) através da Porta Celeste (Porta Eccelsis). O convite está na frase do livro em sua mão direita: "Eu sou o caminho, a verdade e a vida", portanto aceitar o convite e entrar no oratório, cruzar este portal, levar-nos-á ao Reino de Deus-Pai, ao Reino dos Céus.

\section{Considerações finais}

Ao analisar o Christus Militans, desvenda-se um mundo esquecido nos primórdios do cristianismo, um mundo de triunfo e glória, não de martírio e dor, tão bem traduzida por suas tesselas de vidro. Deparamo-nos com uma obra simples, porém repleta de 
simbologia, não à toa um de seus atrativos é sua ressignificação simbólica: de imperial tardia para a paleocristã. Torna-se, portanto, uma janela para tentarmos entender como se deu a transição da religião pagã para a cristã.

Lembremos que o mosaico em questão se encontra na capela particular do mais alto representante da Igreja na capital imperial, fazendo-nos supor que apenas uma elite tinha acesso a este recinto. Dessa maneira, não foi concebida e executada para o povo, mas para uns poucos, para os letrados, afinal não só o Cristo tem um livro em sua mão, como também suas paredes estão repletas de palavras, representadas nos hexâmetros. Certamente, foram os melhores artistas que empregaram os materiais mais nobres à disposição, no auge da arte do mosaico em vidro. A temática é, seguramente, complexa, porém apresentada de forma simples, calma, não passional. Não há um ornamento ou uma informação que não seja essencial. Não há ornamentação pela ornamentação, o horror vacui, presente nas artes plásticas séculos depois.

Do alto da porta de acesso ao oratório, contempla-nos um imperador cristão, o Christus Militans e, ao mesmo tempo, Victor que subjugou a tentação, a soberba, o mal e a morte para salvar seus súditos. Ele nos convida a fazer a passagem, e a entrar em seu Reino: Ego sum Via, Veritas et Vita.

\section{Referências}

ARGAN, G.C. História da Arte Italiana: Da Antiguidade a Duccio, vol.1. São Paulo: Cossac \& Naify, 2003.

BÍBLIA SAGRADA: Edição Pastoral. São Paulo: Edições Paulinas, 1990.

BRANDÃO, A. J. S. Da iconologia à iconofotologia: uma mudança paradigmática. Ghrebh, v.15, São Paulo: PUC/SP, 2010. Disponível em: <http://cisc.org.br/portal/jdownloads/Ghrebh/Ghrebh-\%2015/05 brando.pdf>. Acesso em: 24 fev 2017.

BRANDÃO, J. Apontamentos imagético-interdisciplinares: as artes iconológicas... Embu-Guaçu: Lumen et Virtus, 2014.

BURCKHARDT, T. A ARTE SAGRADA no Oriente e no Ocidente: princípios e métodos. São Paulo: Attar Editorial, 2004.

DIE DEUTSCHEN BISCHÖFE. Der Glaube an den dreieinen Gott: Eine Handreichung der Glaubenskommission der Deutschen Bischofskonferenz zur Trinitätstheologie. Bonn: Herausgegeben vom Sekretariat der Deutschen Bischofskonferenz, 2006.

HORAPOLO. Hieroglyphica (Trad. María José García Soler). Madrid: Akal, 2011. 
RIPA, Ce. Iconología (Tomo I). Madrid: Akal, 2007a.

Iconología (Tomo II). Madrid: Akal, 2007b.

UNESCO. Early Christian Monuments of Ravenna, 1996. Disponível em <http://whc.unesco.org/en/list/788>. Acesso em: 30 mar 2017.

\footnotetext{
i Jack Brandão é Mestre e Doutor em Literatura pela Universidade de São Paulo (USP), Professor Titular do Mestrado Interdisciplinar em Ciências Humanas da Universidade de Santo Amaro (UNISA/SP) e coordenador do Grupo de Pesquisa CONDESIM-FOTÓS/DGP-CAPES, email:jackbran@gmail.com.

ii Christiane Meier é mestranda em Ciências Humanas pela Universidade de Santo Amaro (UNISA/SP), especialista em História da Arte pela Fundação Armando Álvares Penteado (FAAP/SP) e membro do do Grupo de Pesquisa CONDESIM-FOTÓS/DGP-CAPES.

iii Ricardo Alexandre Ramos é mestrando em Ciências Humanas pela Universidade de Santo Amaro (UNISA/SP), especialista Metodologia e Didática do Ensino Superior pela Escola Superior de Administração e membro do Grupo de Pesquisa CONDESIM-FOTÓS/DGP-CAPES.
}

Como citar esse artigo:

BRANDÃO, Jack; MEIER, Christine; RAMOS, Richardo Alexandre. Ravena e o fim do Império Romano Ocidental: construção imagética do Christus Militans. Revista Digital do LAV, Santa Maria: UFSM, v. 11, n. 1, p. 140-160, jan./abr. 2018.

Enviado em: 09 de março de 2017

Aprovado em: 12 de novembro de 2017.

Revista Digital do LAV - Santa Maria - vol. 11, n. 1, p. 140-160 - jan./abr. 2018 ISSN 1983 - 7348 http://dx.doi.org/10.5902/1983734828890 